\title{
Analisis Yuridis Tentang Penerapan Kuota Taksi Online
}

\author{
Juridical Analysis of the Implementation of Online Taxi Quota
}

\author{
Pradita Desyanti \\ Universitas Airlangga \\ E-mail: pradipta.desyanti@fh.unair.ac.id \\ Hilda Yunita Sabrie \\ Universitas Airlangga \\ E-mail: hilda.sabrie@fh.unair.ac.id \\ Yusuf Arif Utomo \\ Universitas Brawijaya \\ E-mail: yusuf24_arif21@yahoo.com
}

\begin{abstract}
Ages has carried the world in the era of globalization. Globalization is wellknown with what is called convenience, high speed and closely related with technology and innovation. Now days, online transportation, especially online taxies become a popular land transportation in public. In order to accommodate the online taxi service, the Government through the Minister of Transportation issued Ministerial Regulation Number 26 of 2017 (currently known as the Minister of Transportation Regulation Number 118 of 2018) concerning the Implementation of Special Rental Transportation as a law for online taxies. In the regulation, there is one Article about quota of online taxi. As it is known that the existence of quota will cause limitation on the number of taxis online which lead to causes pro and cons. Therefore, the questions are how important regulations regarding quota are needed and how to set the quotas to what efforts are made by the Government in implementing the limitation of the quota. Moreover, in terms of applying the quota, online taxi drivers and their users will certainly be affected, either positively and negatively.
\end{abstract}

Keyword: Quota Limitation; Online Taxies; Quota effect

Abstrak: Perkembangan zaman telah menghantarkan dunia pada era globalisasi. Globalisasi identik dengan yang namanya kemudahan, kecepatan, dan berhubungan erat dengan teknologi serta inovasi. Salah satu perkembangan pada era globalisasi adalah sektor transportasi. Jika dulu masyarakat memilih taksi konvensional untuk mendapatkan sarana fasilitas yang aman dan nyaman, maka lain halnya dengan saat ini karena transportasi online khususnya taksi online menjadi sarana transportasi darat yang sedang digemari oleh masyarakat. Hal tersebut sempat 
menimbulkan pro dan kontra di antara para pengemudi. Guna mengakomodasi layanan taksi online tersebut Pemerintah melalui Menteri Perhubungan membuat Peraturan Menteri Nomor 118 Tahun 2018 tentang Penyelenggaraan Angkutan Sewa Khusus sebagai payung hukum dari taksi online. Dalam Peraturan tersebut ada salah satu Pasal yang mengatur mengenai kuota taksi online. Sebagaimana diketahui bahwa adanya kuota akan menyebabkan pembatasan jumlah kendaraan. Kemudian sejauh apa peraturan mengenai penetapan kuota ini dibutuhkan, bagaimana cara menetapkan kuota dan upaya apa saja yang dilakukan oleh Pemerintah dalam mengimplementasikan penetapan kuota tersebut. Selain itu dampak apa saja yang akan dialami oleh pengemudi dan pengguna dari adanya penerapan kuota.

Kata kunci: Penetapan Kuota; Taksi Online; Efek Kuota

\section{PENDAHULUAN}

Perkembangan zaman telah mengubah dunia ke era globalisasi. Globalisasi identik dengan yang namanya kemudahan dan kecepatan. Dampak dari globalisasi hampir pasti dirasakan oleh seluruh lapisan masyarakat dalam setiap aktivitas kehidupan salah satunya dalam hal mobilitas. Dalam melakukan mobilitas tersebut masyarakat membutuhkan transportasi. Saat ini bidang transportasi dipadukan dengan teknologi smartphone yang memiliki banyak sekali keunggulan. Dari perpaduan tersebut kemudian menghasilkan sebuah inovasi di bidang transportasi yang biasa disebut dengan transportasi online. Transportasi online pertama kali diperkenalkan di Amerika dengan sebutan Transportation Network Companies (TNC) yang menyediakan kendaraan berupa mobil atau taksi. ${ }^{1}$ Jika di negara asalnya hanya terdiri dari mobil dan taksi, di Indonesia, transportasi online yang dinaungi oleh Go-Jek dan Grab memiliki banyak variasi mulai layanan transportasi baik kendaraan sepeda motor maupun mobil sekaligus layanan lain seperti pesan antar makanan dan logistik.

Kehadiran taksi online disambut baik oleh masyarakat. Hal ini dapat dibuktikan dengan data dari CNN Indonesia yang menyatakan bahwa aplikasi Go-Jek dan Grab masuk dalam 20 aplikasi terbanyak diunduh di Indonesia. ${ }^{2}$ Dengan membawa model bisnis sharing economy dalam artian konsumen yang memiliki sumber daya kendaraan pribadi dan kemampuan mengemudi saling terikat dengan konsumen yang membutuhkan

1 Aprima Syafrino, Efektifitas dan Dampak Ojek Online Terhadap kesempatan Kerja dan Kesejahteraan, Skripsi, Bogor: Institut Pertanian Bogor, 2017, hlm. 1.

2 CNN Indonesia, Geliat Bisnis Transportasi Online, YouTube, https://www.youtube.com/ watch?v=oDEQIPr5m0U. 21 Maret 2017, diakses pada tanggal 17 Juni 2018. 
pelayanan jasa yang berupa transportasi dengan memberikan nilai transaksi yang wajar ${ }^{3}$ membuat masyarakat tertarik untuk menjadi pengemudi taksi online. Terlebih menjadi pengemudi taksi online memiliki berbagai keuntungan seperti waktu kerja fleksibel, tidak menghabiskan waktu di jalan, dapat menunggu penumpang di mana pun bahkan di rumah, dan berbagai keuntungan lain yang mungkin tidak didapatkan ketika menjadi pekerja di sebuah perusahaan.

Kehadiran transportasi online memang menuai pro dan kontra, pasalnya sejak ada transportasi online (pembahasan ini akan difokuskan kepada taksi online) angkutan umum lain dan taksi konvensional mengalami penurunan penumpang. Akibatnya pendapatan mereka menjadi berkurang. Kondisi ini sempat menyebabkan pengemudi taksi online melakukan aksi demonstrasi. Terlebih payung hukum taksi online pada saat itu belum tersedia sehingga adanya taksi online dianggap sebagai sesuatu yang ilegal. Guna menjawab persoalan tersebut Pemerintah melalui Kementerian Perhubungan (Kemenhub) akhirnya merespons hal tersebut dengan memasukkan aturan taksi online dalam Peraturan Menteri Perhubungan Nomor 26 Tahun 2017 tentang Penyelenggaraan Angkutan Orang Dengan Kendaraan Bermotor Umum Tidak Dalam Trayek (PM 26/2017). Namun, tidak beberapa waktu kemudian beberapa Pasal dalam peraturan tersebut dibatalkan oleh Mahkamah Agung (MA) sehingga Kemenhub kembali memperbarui dengan Peraturan Menteri Perhubungan Nomor 108/2017 (PM 108/2017) yang merevisi ketentuan seperti argometer, tarif, wilayah operasi, kuota atau perencanaan kebutuhan, persyaratan minimal 5 kendaraan, bukti kepemilikan kendaraan bermotor, domisili tanda nomor kendaraan bermotor (TNKB), sertifikasi uji tipe dan peran aplikator. Meski telah diperbarui, MA kembali membatalkan beberapa Pasal yang tercantum dalam Putusan Mahkamah Agung Nomor 15/P/HUM 2018. Baru-baru ini Kemenhub kembali mengeluarkan peraturan baru yang mengakomodasi taksi online. Peraturan tersebut adalah Peraturan Menteri Nomor 118 Tahun 2018 tentang Penyelenggaraan Angkutan Sewa Khusus. Salah satu hal yang menurut penulis menarik untuk dikaji adalah penetapan kuota taksi online yang ketentuannya diatur dalam pasal 8 sampai Pasal 10 PM 118/2018.

3 Aprima Syafrino, Op. cit., hlm. 7. 


\section{ANALISIS DAN PEMBAHASAN}

\section{Urgensi Penetapan Kuota Taksi Online}

Pesatnya pertumbuhan transportasi online di Indonesia khususnya taksi online dianggap menjadi salah satu kesempatan bagi sebagian orang untuk mencari penghasilan atau bahkan menambah penghasilan. Kehadiran jasa transportasi on demand secara online telah mengubah wajah industri transportasi. Jika dulu perusahaan transportasi konvensional mampu mengusai sebuah kota dan bersaing dengan sesama taksi konvensional, maka lain halnya dengan saat ini ketika mereka harus berhadapan dengan aplikator yang bermodalkan teknologi sebagaimana yang diinginkan oleh konsumen. ${ }^{4}$

Merujuk pada Undang-Undang Republik Indonesia No. 22 Tahun 2009 tentang Lalu Lintas dan Angkutan Darat (UU LLAJ) Pasal 140 mengenai angkutan orang dengan kendaraan bermotor yang terdiri dari 2 kategori yakni angkutan orang dengan kendaraan bermotor umum dalam trayek dan angkutan orang dengan kendaraan bermotor umum tidak dalam trayek. Dalam penjelasannya, yang dimaksud dengan "trayek" adalah lintasan Kendaraan Bermotor Umum untuk pelayanan jasa angkutan yang mempunyai asal dan tujuan perjalanan tetap, serta lintasan tetap, baik berjadwal maupun tidak. Sehingga yang dimaksud dengan tidak dalam trayek adalah pelayanan jasa angkutan yang mempunyai asal dan tujuan perjalanan tidak tetap. Melihat karakteristik taksi online yang tidak memiliki asal yang tetap serta tujuan perjalanan yang bervariasi bergantung pada pemesanan yang dilakukan konsumen, maka taksi online dapat dikategorikan sebagai angkutan kendaraan bermotor umum tidak dalam trayek.

Beberapa jenis angkutan kendaraan bermotor umum tidak dalam trayek diatur dalam Pasal 151 yakni:

Pelayanan angkutan orang dengan Kendaraan Bermotor Umum tidak dalam trayek sebagaimana diatur dimaksud dalam Pasal 140 huruf b terdiri atas:

(a) Angkutan orang dengan menggunakan taksi;

(b) Angkutan orang dengan tujuan tertentu;

(c) Angkutan orang untuk keperluan pariwisata; dan

(d) Angkutan orang di kawasan tertentu.

Taksi online dikategorikan sebagai angkutan sewa khusus yang masuk dalam jenis angkutan orang dengan tujuan tertentu karena taksi adalah angkutan umum yang melayani penumpang tidak dalam trayek serta memiliki ciri-ciri kendaraan berpelat hitam,

4 Ahmad Bambang, Marketing Platform for BUMN: d;Gil! Marketing 2, Jakarta: Gramedia Pustaka Utama, 2017. hlm. 56. 
tidak memakai argometer, dan tidak memiliki identitas khusus. Sedangkan taksi konvensional yang kita kenal selama ini memiliki ciri-ciri seperti pelat kuning, memakai argometer serta identifikasi “taksi” pada bodi kendaraan. Guna tetap mengakomodasi jenis angkutan taksi online maka dibuatlah nomenklatur angkutan sewa khusus atau bisa disebut juga angkutan sewa online. Artinya secara hukum Pemerintah mengakui keberadaan angkutan yang berbasis aplikasi tersebut. ${ }^{5}$

Banyaknya pengemudi taksi online saat ini membuat Pemerintah mengeluarkan regulasi terkait rencana kebutuhan kendaraan yang diperuntukkan untuk transportasi online roda empat atau taksi online (penetapan kuota). Menurut Kamus Besar Bahasa Indonesia (KBBI) definisi kuota adalah jumlah yang sudah ditentukan. ${ }^{6}$ Peraturan tentang kuota diharapkan dapat menjadi salah satu alternatif untuk menekan jumlah pengemudi taksi online yang semakin lama semakin meningkat dan dapat berdampak pada semakin banyaknya volume kendaraan. Padahal salah satu yang menjadi nilai plus dari hadirnya transportasi online ini adalah karena masyarakat sudah jenuh dengan kondisi lalu lintas yang cukup padat dan melelahkan.

Peraturan mengenai taksi online diatur dalam PM 118/2018. Definisi dari taksi online atau yang disebut angkutan sewa khusus dalam PM ini adalah:

"pelayanan angkutan dari pintu ke pintu dengan pengemudi, memiliki wilayah operasi dalam wilayah perkotaan, dari dan ke bandar udara, pelabuhan, atau simpul transportasi lainnya serta pemesanan menggunakan aplikasi berbasis teknologi informasi, dengan besaran tarif tercantum dalam aplikasi”.

Berkaitan dengan wilayah maka Pasal 7 mengakomodasi taksi online agar tidak terjadi kepadatan di satu titik tertentu pada jam tertentu dengan mempertimbangkan beberapa hal di bawah ini seperti:
a. Penetapan klasifikasi kawasan perkotaan;
b. Perkiraan kebutuhan jasa angkutan sewa khusus;
c. Perkembangan daerah kota atau perkotaan; dan
d. Tersedianya prasarana jalan yang memadai.

\footnotetext{
5 Biro Komunikasi dan Informasi Publik, Mengenal Dan Memahami PM 108 Tahun 2017, Kementerian Perhubungan Republik Indonesia, http://dephub.go.id/post/read/mengenal-dan-memahami-pm-108tahun-2017, diakses pada tanggal 17 Juni 2018.

6 Badan Pengembangan dan Pembinaan Bahasa, Kuota, Kamus Besar Bahasa Indonesia (KBBI) Daring, https://kbbi.kemdikbud.go.id/entri/kuota, diakses pada tanggal 12 Oktober 2018.
} 
Wilayah operasi tersebut ditetapkan Menteri untuk wilayah operasi angkutan sewa khusus yang melampaui 1 (satu) daerah provinsi dan melampaui 1 (satu) daerah provinsi di wilayah Jabodetabek serta Gubernur untuk wilayah operasi yang melampaui 1 (satu) daerah kabupaten/kota daerah provinsi. Wilayah operasi ini maksudnya adalah taksi online hanya diperbolehkan mengambil penumpang sesuai dengan pelat kendaraannya sehingga pengaturannya diharapkan dapat mewujudkan situasi transportasi darat yang lebih baik dan tertib. ${ }^{7}$

Peraturan mengenai kuota tercantum dalam Pasal 8 sampai 10 PM 118/2018. Berdasarkan Pasal 8 bahwa untuk memenuhi kebutuhan pelayanan angkutan sewa khusus perlu disusun rencana kebutuhan kendaraan yang paling sedikit meliputi kegiatan:

a. Penelitian potensi bangkitan perjalanan;

b. Penentuan variabel yang berpengaruh terhadap bangkitan perjalanan;

c. Penentuan model perhitungan bangkitan perjalanan;

d. Perhitungan bangkitan perjalanan untuk kondisi sekarang dan 5 (lima) tahun yang akan datang; dan

e. Pengkonversian jumlah kendaraan bermotor umum dengan mempertimbangkan:

1. Tingkat penggunaan kendaraan bermotor umum; dan

2. Kapasitas kendaraan bermotor umum yang akan melayani.

Kemudian dalam Pasal 9 Perencanaan kebutuhan kendaraan angkutan sewa khusus yang ditetapkan oleh Menteri dan Gubernur sesuai dengan kewenangannya setelah dilakukan kajian dengan pemangku kepentingan yang paling sedikit memuat perkiraan kebutuhan jasa angkutan sewa khusus, kebutuhan kendaraan bermotor umum angkutan sewa khusus untuk melayani permintaan jasa angkutan orang dan alokasi kebutuhan untuk masing-masing daerah. Rencana kebutuhan tersebut wajib diumumkan kepada masyarakat dan digunakan sebagai dasar dalam pembinaan dan dapat dilakukan evaluasi berdasarkan Pasal 10.

Dalam implementasinya ada beberapa Provinsi yang sudah menetapkan kuota taksi online. Salah satunya adalah Provinsi Jawa Timur. Ketentuan tersebut yang diatur dalam Keputusan Gubernur Jawa Timur Nomor 188/375/KPTS/013/2017 tentang Penetapan

7 Biro Komunikasi dan Informasi Publik (selanjutnya disebut Biro Komunikasi dan Informasi Publik II), Pemerintah Beri Kepastian Hukum Melalui Aturan Angkutan Sewa Khusus, Kementerian Komunikasi dan Informatika Republik Indonesia, https://www.kominfo.go.id/content/detail/11395/pemerintah-berikepastian-hukum-melalui-aturan-angkutan-sewa-khusus/0/berita. diakses pada tanggal 9 Januari 2019. 
Alokasi Jumlah Kebutuhan Kendaraan Angkutan Sewa Khusus Aplikasi Berbasis Teknologi Informasi (Online) di Provinsi Jawa Timur. Kuota yang ditetapkan yakni sebanyak 4.445

Berbagai pertimbangan yang dikombinasikan untuk menentukan jumlah kuota tersebut adalah jumlah penduduk, pendapatan per kapita, jumlah angkutan umum yang ada di daerah tersebut serta kondisi wilayah, analisa bangkitan perjalanan (berapa masyarakat yang melakukan perjalanan di daerah), trip assignment (rutenya ke mana saja) serta distribusi perjalanan (pergerakannya ke mana saja) moda speed (penggunaan moda) yang dapat dilihat dari jumlah motor, jumlah mobil, jumlah bis dan lainnya. ${ }^{8}$

Wilayah operasi dan kuota adalah dua elemen yang baik untuk diatur dan dijalankan karena apabila wilayah operasi sudah ditetapkan, tetapi disisi lain pengemudi terus bertambah dan tidak dibatasi maka ruang lalu lintas menyempit. PM ini adalah bagian dari bentuk kepastian hukum, usaha, dan perlindungan yang diberikan oleh Pemerintah kepada para pihak dalam bisnis taksi online sehingga mereka akan mendapatkan perlindungan dan legitimasinya. ${ }^{9}$ Kembali, Arjani mengatakan dalam hal menyikapi transportasi online Pemerintah tidak hanya mengatur mengenai keselamatan dalam segi transportasi tetapi juga dalam segi finansial untuk tetap menjaga pendapatan pengemudi. Dari pernyataan tersebut dapat diketahui pula bahwa regulasi mengenai kuota dimaksudkan untuk menjaga keseimbangan antara kesediaan dan permintaan (supply dan demand) yang dinilai sangat penting. Penetapan kuota bukan hanya menjaga kepentingan konsumen, tetapi juga penyedia jasa termasuk pengemudi karena jika wilayah operasi tidak diatur dan jumlah kendaraan tidak dibatasi maka yang terjadi adalah over supply. Selain menambah beban jalan, penghasilan pengemudi juga akan menurun apabila banyak angkutan sejenisnya yang beroperasi.

Dalam mengimplementasikan kuota Pemerintah telah membuat arahan mengenai pemberhentian (moratorium) pendaftaran mitra taksi online untuk menekan jumlah pengemudi yang semakin lama semakin meningkat. Hingga saat ini jumlah pengemudi taksi online mencapai 175.000 pada satu aplikator di Jabodetabek. Padahal keberadaan taksi online tidak hanya di Jabodetabek. Fakta ini menjadi bukti bahwa pertumbuhan pengemudi taksi online sangat pesat. Jika perekrutan terus dilakukan maka yang terjadi adalah jumlah pengemudi terus bertambah dan dapat mengakibatkan persaingan di

8 Wawancara dengan Arjani Hia Putra Ketua Bidang Angkutan dan Keselamatan Jalan Dinas Perhubungan Provinsi Jawa Timur, 21 November 2018.

9 Biro Komunikasi dan Komunikasi Publik II, Loc. cit. 
antara para pengemudi taksi online. ${ }^{10}$ Salah satu aplikator yakni Grab melalui Managing Director mengatakan sudah tidak membuka perekrutan untuk pengemudi. Grab sedang menjalankan penyesuaian di beberapa daerah secara bertahap. Moratorium ini akan dicoba selama satu bulan, apabila ada aplikator yang tidak memenuhi peraturan maka Pemerintah akan memberikan sanksi.11 Terkait sanksi apa yang akan diberikan Pemerintah kepada aplikator yang masih membuka rekrutmen pengemudi baru memang belum ditetapkan. Namun, di dalam PM 118/2018 khususnya Bab IX Ketentuan Peralihan ayat (3), ayat (4) dan ayat (5) juga telah mengatur bahwa Perusahaan Aplikasi (aplikator) dilarang membuka pendaftaran pengemudi baru setelah ditetapkan besaran kuota, tetapi hal tersebut tidak berlaku apabila terjadi adanya penggantian kendaraan, terputusnya kemitraan. Artinya ketika terdapat hal-hal yang menyebabkan jumlah pengemudi berkurang padahal jumlah kuota masih belum terpenuhi maka aplikator boleh melakukan pendaftaran kemitraan baru, tetapi pendaftaran kemitraan baru tersebut baru dapat dilaksanakan kembali setelah adanya evaluasi dari Menteri atau Gubernur sesuai dengan kewenangannya.

Selain melakukan moratorium, Kementerian Perhubungan (Kemenhub) bekerja sama dengan Kementerian Komunikasi dan Informasi (Kominfo) mengenai sistem pemantau yang dapat menampilkan taksi online yang aktif dan beroperasi. Sistem pemantau tersebut akses dan otorisasinya akan diberikan ke Kemenhub dan Dishub tingkat Provinsi dan kemudian akses tersebut dapat menuju domain Kominfo. Setelah masuk sistem pemantau, pengakses dapat melihat berbagai platform seperti Go-Jek dan Grab. Dinas Perhubungan tingkat Provinsi dapat melihat sistem pemantau sesuai wilayahnya masing-masing. ${ }^{12}$ Berdasarkan Pasal 28 ayat (2) PM 118/2018 akses digital dashboard paling sedikit memuat nama perusahaan, penanggung jawab, dan alamat perusahaan aplikasi, data seluruh perusahaan angkutan sewa khusus yang bekerja sama,

10 Fadhly F Rachman, Lampaui Kuota, Sopir Taksi Online Capai 175 ribu per Operator, Detikcom, https://finance.detik.com/berita-ekonomi-bisnis/d-3912235/lampaui-kuota-sopir-taksi-online-capai175-ribu-per-operator., diakses pada tanggal 20 Oktober 2018.

11 Chitra Paramaesti, Grab Tidak Buka Perekrutan Driver Lagi, Tempo, https://bisnis.tempo.co/read/ 1072551/grab-tidak-buka-perekrutan-pengemudi-lagi/full\&view=ok., diakses pada tanggal 28 Oktober 2018.

12 Biro Humas Kementerian Komunikasi dan Informasi, Kesepakatan Dashboard Transportasi Online antara Kementerian Kominfo dan Kementerian Perhubungan (Siaran Pers No. 43/HM/KOMINFO/02/2018, Kementerian Komunikasi dan Informatika Republik Indonesia, https://kominfo.go.id/content/detail/ 12609/siaran-pers-no-43hmkominfo022018-tentang-kesepakatan-dashboard-transportasi-onlineantara-kementerian-kominfo-dan-kementerian-perhubungan/0/siaran_pers, diakses pada tanggal 26 Oktober 2018. 
data seluruh kendaraan dan pengemudi, akses monitoring operasional pelayanan berupa data transaksi pemesanan melalui aplikasi termasuk asal dan tujuan perjalanan dan tarif, layanan pengaduan konsumen berupa telepon dan surat elektronik perusahaan aplikasi.

\section{Dampak Penerapan Kuota Bagi Pengemudi dan Pengguna Taksi Online}

Kewajiban pengemudi sebagai pengangkut dalam pengangkutan di darat secara lex generalis tunduk pada Burgelijk Wetboek (BW) yang tercantum dalam Pasal 1234 sampai dengan Pasal 1338 BW yang kemudian dipertegas dalam Pasal 91 dan 92 Wetboek Van Koophandel atau Kitab Undang-Undang Hukum Dagang (KUHD) sebagai lex specialis. ${ }^{13}$

Pasal 1338 BW mengatur bahwa:

(1) Semua Perjanjian yang dibuat secara sah berlaku sebagai undang-undang bagi mereka yang membuatnya;

(2) Perjanjian itu tidak dapat ditarik kembali selain dengan sepakat kedua belah pihak atau karena alasan-alasan yang oleh undang-undang dinyatakan cukup untuk itu;

(3) Perjanjian harus dilaksanakan dengan itikad baik.

Berdasarkan ayat terakhir maka pengangkut berkewajiban untuk beritikad baik dalam suatu perjanjian pengangkutan. Dalam perjanjian pengangkutan penumpang taksi online maka pengemudi wajib mengambil pesanan/mengorder dengan itikad baik. Selain itu berdasarkan Pasal 1243, 1244, 1245 BW juga perlu dicermati mengenai kewajiban pengangkut dalam hal mengganti kerugian bila terjadi kerugian pada yang diangkutnya maka pengangkut wajib mengganti kerugian tersebut kecuali adanya kerugian disebabkan oleh keadaan atau situasi di luar kehendak pengemudi (overmacht). Lebih jelasnya 1244 BW mengatur bahwa pengangkut berkewajiban mengganti kerugian apabila tidak memenuhi perikatan kecuali terdapat alasan yang dapat membebaskan pengangkut untuk tidak mengganti kerugian seperti saat pengangkut dalam keadaan overmacht. Keadaan overmacht adalah keadaan yang tidak dapat dihindari oleh manusia pada umumnya. Namun, Sukardono memberikan batasan penafsiran berbeda. Bahwa tidak setiap terjadi keadaan overmacht dan pengangkut dapat membuktikan bahwa kerugian tersebut diakibatkan dari bahaya overmacht kemudian pengangkut tersebut bebas dari tanggung jawab. Lebih dari itu overmacht harus dimaknai secara objektif dan subjektif. Secara

13 Wuri Adriyani dan Samzari Boentoro, Buku Ajar Hukum Pengangkutan, Surabaya: Fakultas Hukum Universitas Airlangga, 2007, hlm. 23. 
objektif yaitu harus terjadi overmacht suatu bahaya yang tidak dapat dicegah akan terjadinya misalnya ketika terjadi gempa secara tiba-tiba. Selanjutnya secara subjektif yaitu pengangkut harus berupaya dalam hal terjadi overmacht untuk mencegah, mengurangi, dan memperkecil terjadinya kerugian misalnya untuk mengurangi risiko kecelakaan pengemudi harus rutin memeriksa kondisi kendaraannya. Di sinilah dapat dilihat apakah ganti rugi akibat overmacht perlu dibebankan atau tidak. ${ }^{14}$

Berkaitan dengan Pasal 1367 ayat (1) BW yang mengatur bahwa

"seseorang tidak hanya bertanggung jawab atas kerugian yang disebabkan perbuatannya sendiri, melainkan juga atas kerugian disebabkan perbuatan orangorang yang menjadi tanggungannya, atau disebabkan barang-barang yang berada di bawah pengawasannya".

Berdasarkan ketentuan tersebut maka pihak aplikator sebagai penyedia jasa yang menaungi para pengemudi taksi online juga dapat dikenai tanggung jawab atas kelalaian yang dilakukan oleh pengemudi. Hal tersebut juga tercantum dalam Pasal 17 huruf g PM 118/2018: Perusahaan angkutan sewa khusus sebagaimana dimaksud dalam Pasal 11 ayat (1) harus:

g. Mengasuransikan tanggung jawab, yaitu berupa iuran wajib dan tanggung jawab pengangkut.

Grab sendiri memberikan gambaran umum asuransi kecelakaan dalam website resminya. Grab menanggung polis bagi pengemudi yang memenuhi syarat dan penumpang yang memesan dan membayar yang telah memesan dan berkendara dengan Grab. Dalam kebijakan tersebut Grab merancang untuk memberikan kompensasi bergantung pada cedera tubuh yang timbul akibat kecelakaan saat berkendara menggunakan Grab terlepas dari siapa yang salah. Rinciannya adalah kematian pengemudi 25.000.000 dan penumpang 50.000.000. Cacat permanen masing-masing 25.000.000 dan biaya pengobatan akan diganti maksimal 25.000 .000 baik untuk pengemudi maupun penumpang. ${ }^{15}$

Dengan demikian maka kewajiban pengangkut secara umum adalah menyelenggarakan pengangkutan dengan aman dan selamat sampai tujuan serta mengganti kerugian apabila terjadinya kerugian dapat dibuktikan bahwa kejadian tersebut akibat dari lalainya pengangkut. ${ }^{16}$ Setelah menjalankan kewajibannya maka

14 Ibid, hlm. 25.

15 Grab, Gambaran Umum Asuransi Kecelakaan Personal Grab!, Grab, https://www.grab.com/id/insurance/, diakses pada 9 Januari 2019.

16 Wuri Adriyani dan Samzari Boentoro, Loc. cit. 
sebagai penyeimbang atas prestasi yang dilakukan pengemudi maka pengemudi selaku pengangkut berhak memperoleh upah angkutan sebagaimana yang telah disetujui dalam perjanjian pengangkutan. Dalam hal ini Pasal 94 KUHD menjamin pengangkut untuk mendapatkan upah angkutan. Selain itu pengangkutjuga berhak untuk menolak pengajuan ganti rugi oleh penumpang dengan alasan atau bukti-bukti bahwa kerugian tersebut disebabkan bukan karena kesalahannya. ${ }^{17}$ Sejalan dengan Pasal 234 UU LLAJ bahwa pengemudi, pemilik kendaraan bermotor, dan/atau perusahaan angkutan bertanggung jawab atas kerugian yang diderita penumpang dan/atau pemilik barang dan/atau pihak ketiga karena kelalaian pengemudi kecuali jika kerugian tersebut diakibatkan karena adanya keadaan memaksa yang tidak dapat diprediksi, disebabkan oleh perilaku korban sendiri atau pihak ketiga yang bersangkutan dan/atau disebabkan gerakan orang dan/atau hewan walaupun telah diambil tindakan pencegahan.

Sebagai suatu perjanjian kewajiban utama dari para pihak adalah melaksanakan perjanjian dengan itikad baik. Kemudian mengingat taksi online menggunakan sistem aplikasi maka perlu juga merujuk pada Undang-undang Nomor 11 tahun 2008 tentang Informasi dan Transaksi Elektronik (UU ITE) sebagaimana telah diubah oleh UndangUndang Nomor 19 Tahun 2016 tentang Perubahan Atas Undang-Undang Nomor 11 Tahun 2008 tentang Informasi dan Transaksi Elektronik. Dalam Pasal 1 angka 2 UU ITE transaksi elektronik adalah perbuatan hukum yang dilakukan dengan menggunakan komputer, jaringan, komputer, maupun media elektronik. Definisi tersebut sesuai dengan proses pemesanan taksi online yang menggunakan jaringan internet melalui perangkat elektronik yaitu smartphone. Pasal 17 (2) UU ITE juga menegaskan bahwa para pihak yang melakukan transaksi elektronik wajib beritikad baik. Jika pengangkut berhak mendapatkan upah angkutan sebagai ganti atas prestasi mengangkut maka penumpang wajib membayar biaya angkutan tersebut. Kemudian apabila pengangkut wajib memberikan pelayanan yang aman dan selamat maka hak penumpang adalah mendapatkan pelayanan angkutan yang aman dan selamat. Terakhir, jika pengangkut berkewajiban mengganti kerugian saat dapat dibuktikan kesalahan maka sebaliknya penumpang berhak memperoleh ganti kerugian akibat kesalahan pengangkut. ${ }^{18}$

Ibid, hlm. 27.

18 Ibid, hlm. 60. 
Selanjutnya berkaitan dengan kuota taksi online, penulis mencoba menjabarkan dampak apa saja yang akan dirasakan oleh pengemudi dan pengguna aplikasi dari adanya peraturan kuota taksi online.

Berikut uraian dampak yang dirasakan oleh pengemudi dan pengguna berdasarkan wawancara yang telah dilakukan oleh penulis:

\section{Dampak Positif Penetapan Kuota Bagi Pengemudi}

Pengemudi dapat menerima order secara maksimal

Saat ini jumlah pengemudi yang banyak membuat pengemudi harus menunggu lebih lama order yang masuk karena aplikator harus membagi order kepada beberapa pengemudi. Akibatnya penghasilan pengemudi menurun (khususnya bagi pengemudi lama). Jika di bab sebelumnya menjadi pengemudi taksi online dapat mengantongi jumlah yang cukup banyak, maka berbeda dengan kondisi saat ini. Banyak pengemudi lama taksi online yang mengaku sudah jarang bahkan tidak pernah lagi memperoleh penghasilan seperti awal mereka bergabung dengan perusahaan taksi online. Hal ini tentu menjadi aspek konkret mengapa Pemerintah perlu membuat penetapan kuota. Ada tiga pengemudi yang berhasil diwawancara oleh penulis. Ketiganya adalah Joko Dwi Ratnowo (pengemudi Grab), Rudi Hermawan (pengemudi Go-Car) dan Naswa Agus (pengemudi Grab). Menurut Joko saat ini dirinya sulit mendapatkan order karena sudah banyak pengemudi taksi online. Lain halnya dengan Rudi yang mengatakan bahwa saat ini order sudah diacak oleh pusat. Jadi semakin aktif seorang pengemudi maka semakin banyak pula order yang akan masuk dan sebaliknya. Sehingga daya saing di sini akan diperhatikan. Bagi pengemudi yang memiliki pekerjaan lain mungkin akan kesulitan, tetapi bagi yang menjadikan taksi online sebagai lapangan pekerjaan tentu mereka akan mendapatkan hasil maksimal. Lain halnya dengan Naswa yang menjelaskan bahwa pengemudi dalam Grab dikategorikan dalam beberapa bagian. Semakin baik kategori pencapaian berdasarkan bintang yang didapat oleh pengemudi maka order yang masuk akan semakin banyak, tetapi Naswa tidak menyangkal bahwa jika dibandingkan dengan dua tahun lalu saat awal-awal dirinya menjadi pengemudi, tentu saat ini pendapatannya tidak sebanyak dulu.

\section{Dampak Negatif Penetapan Kuota Bagi Pengemudi}

Mekanisme Belum Jelas

Sampai saat ini penetapan kuota diterapkan secara perlahan di berbagai Provinsi termasuk Jawa Timur. Jawa Timur menetapkan kuota sebanyak 4.445. Namun, hanya 140 
unit yang sudah mendapatkan izin. Padahal taksi online yang beredar di Jawa Timur diperkirakan ada 10.000 unit $^{19}$. Hal ini dapat menjadi sesuatu yang kurang adil bagi pengemudi yang bersungguh-sungguh untuk mematuhi kebijakan Pemerintah karena dalam praktiknya para pengemudi yang belum memenuhi persyaratan pun masih dapat beroperasi. Sehingga dapat dikatakan implementasi kuota saat ini masih belum maksimal.

\section{Kehilangan Pekerjaan}

Telah dijelaskan sebelumnya bahwa jumlah taksi online yang beroperasi saat ini diperkirakan mencapai 10.000. Padahal kuota yang telah ditetapkan oleh Pemerintah Jawa Timur hanya 4.445. Sehingga dengan adanya penetapan kuota maka sebanyak 5.455 pengemudi taksi online berpotensi tidak akan dapat menerima order lagi, tetapi yang perlu diingat 10.000 pengemudi tersebut adalah jumlah secara keseluruhan karena tidak semua pengemudi menjadikan taksi online sebagai lahan pekerjaan utama bagi mereka.

\section{Dampak Positif Penetapan Kuota Bagi Pengguna}

\section{Pelayanan Lebih Maksimal}

Ketika ditetapkan kuota maka pengemudi akan mematuhi berbagai persyaratan yang ditetapkan oleh Pemerintah agar pengemudi dapat masuk dalam pemenuhan kuota. Dalam hal ini pengguna menjadi diuntungkan karena hanya pengemudi yang memenuhi syarat yang akan mendapat legalitas untuk beroperasi. Sehingga keamanan penumpang lebih terjamin.

\section{Dampak Negatif Penetapan Kuota Bagi Pengguna}

\section{Waktu Tunggu Lebih Lama}

Konsekuensi logis dari adanya penetapan kuota adalah jumlah pengemudi yang berkurang. Dengan jumlah pengguna yang banyak maka perlu diseimbangkan dengan jumlah pengemudi yang ada. Jika Pemerintah hanya akan memberikan izin kepada pengemudi yang telah memenuhi persyaratan maka hanya ada 140 pengemudi yang dapat beroperasi. Padahal jumlah pengguna dipastikan lebih dari angka tersebut. Ketika permintaan lebih banyak daripada penawaran maka yang terjadi adalah over demand.

19 Wijayanto, Belum Ditindak, Dishub Baru Lakukan Pendataan, Radar Surabaya, https://radarsurabaya.jawapos.com/read/2018/02/08/47454/belum-ditindak-dishub-baru-lakukanpendataan. diakses pada tanggal 8 November 2018. 
Dengan demikian calon penumpang harus menunggu lebih lama bahkan sangat lama untuk memastikan pengemudi mengambil order mereka. Beberapa pengguna taksi online mengatakan bahwa mereka sempat kesulitan mendapatkan pengemudi di tempat-tempat tertentu serta membutuhkan waktu lebih lama untuk mendapatkan pengemudi dibandingkan dengan awal kemunculan taksi online.

Dalam wawancara yang dilakukan oleh penulis dengan tiga pengemudi yang masih sama dengan sebelumnya dua di antaranya tidak mengerti mengenai kuota, hanya Naswa yang memahami bahkan mengikuti perkembangan regulasi mengenai taksi online sehingga diperlukan berbagai upaya guna memantau para pengemudi agar tidak berhenti menjadi mitra begitu saja ketika mereka mengetahui berbagai kebijakan yang dirasa sulit, karena ketika ada pengemudi yang berhenti maka kuota yang sudah ditetapkan menjadi berkurang dan efeknya dapat memengaruhi waktu tunggu pengguna saat melakukan pemesanan taksi online. Kondisi sebaliknya yakni apabila penetapan kuota tidak berlaku efektif maka peraturan ini berdampak pada pengemudi yang sudah berusaha mengikuti peraturan Pemerintah agar mereka dapat dimasukkan dalam pemenuhan kuota yang artinya mereka telah mengeluarkan biaya untuk hal itu.

\section{KESIMPULAN}

Penetapan kuota dihitung oleh Dinas Perhubungan Kota/Kabupaten berdasarkan beberapa pertimbangan yang bertujuan untuk menjaga keselamatan penumpang dan mempertahankan pendapatan pengemudi. Hingga saat ini upaya yang telah dilakukan Pemerintah untuk mengimplementasikan kuota adalah moratorium dan pemantauan melalui akses dashboard. Namun, proses implementasi kuota tersebut masih terdapat kendala salah satunya adalah penerapan kuota pada lingkup region. Dengan demikian maka peraturan mengenai penetapan kuota memang perlu dilakukan untuk tetap menjaga supply dan demand khususnya di masing-masing wilayah karena kuota erat kaitannya dengan wilayah operasi. Secara keseluruhan dapat dikatakan bahwa ketika penetapan kuota berlaku efektif maka pengemudi akan lebih maksimal dalam menerima order artinya mereka akan memperoleh penghasilan yang cukup besar. Kemudian pada sisi lain penumpang juga akan mendapatkan pelayanan terbaik karena hanya pengemudi taksi online yang memenuhi kriteria yang dapat beroperasi. Namun, yang perlu diperhatikan adalah untuk menjadikan regulasi kuota efektif diperlukan mekanisme yang tidak mudah 
mengingat tidak semua orang menjadikan taksi online sebagai satu-satunya lahan pekerjaan mereka.

\section{Daftar Pustaka}

\section{Buku}

Adriyani, Wuri dan Samzari Boentoro, Buku Ajar Hukum Pengangkutan, Surabaya: Fakultas Hukum Universitas Airlangga, 2007.

Bambang, Ahmad, Marketing Platform for BUMN: d;Gil! Marketing 2, Jakarta: Gramedia Pustaka Utama, 2017.

Syafrino, Aprima, Efektifitas dan Dampak Ojek Online Terhadap kesempatan Kerja dan Kesejahteraan, Skripsi, Bogor: Institut Pertanian Bogor, 2017.

\section{Situs Web}

Badan Pengembangan dan Pembinaan Bahasa, Kuota, Kamus Besar Bahasa Indonesia (KBBI) Daring, https://kbbi.kemdikbud.go.id/entri/kuota, diakses pada tanggal 12 Oktober 2018.

Biro Humas Kementerian Komunikasi dan Informasi, Kesepakatan Dashboard Transportasi Online antara Kementerian Kominfo dan Kementerian Perhubungan (Siaran Pers No. 43/HM/KOMINFO/02/2018, Kementerian Komunikasi dan Informatika Republik Indonesia, https://kominfo.go.id/content/detail/12609/siaran-pers-no-43hmko minfo022018-tentang-kesepakatan-dashboard-transportasi-online-antara-kemen terian-kominfo-dan-kementerian-perhubungan/0/siaran_pers, diakses pada tanggal 26 Oktober 2018.

Biro Komunikasi dan Informasi Publik (selanjutnya disebut Biro Komunikasi dan Informasi Publik II), Pemerintah Beri Kepastian Hukum Melalui Aturan Angkutan Sewa Khusus, Kementerian Komunikasi dan Informatika Republik Indonesia, https://www.kominfo.go.id/content/detail/11395/pemerintah-beri-kepastianhukum-melalui-aturan-angkutan-sewa-khusus/0/berita. diakses pada tanggal 9 Januari 2019.

Biro Komunikasi dan Informasi Publik, Mengenal Dan Memahami PM 108 Tahun 2017, Kementerian Perhubungan Republik Indonesia, http://dephub.go.id/post/read/ mengenal-dan-memahami-pm-108-tahun-2017, diakses pada tanggal 17 Juni 2018. 
CNN Indonesia, Geliat Bisnis Transportasi Online, YouTube, https://www.youtube.com/ watch?v=oDEQIPr5m0U. 21 Maret 2017, diakses pada tanggal 17 Juni 2018.

Grab, Gambaran Umum Asuransi Kecelakaan Personal Grab!, Grab, https://www.grab.com/id/insurance/, diakses pada 9 Januari 2019.

Paramaesti, Chitra, Grab Tidak Buka Perekrutan Driver Lagi, Tempo, https://bisnis.tempo.co/read/ 1072551/grab-tidak-buka-perekrutan-pengemudilagi/full\&view=ok., diakses pada tanggal 28 Oktober 2018.

Rachman, Fadhly F., Lampaui Kuota, Sopir Taksi Online Capai 175 ribu per Operator, Detikcom, https://finance.detik.com/berita-ekonomi-bisnis/d-3912235/lampauikuota-sopir-taksi-online-capai-175-ribu-per-operator., diakses pada tanggal 20 Oktober 2018.

Wijayanto, Belum Ditindak, Dishub Baru Lakukan Pendataan, Radar Surabaya, https://radarsurabaya.jawapos.com/read/2018/02/08/47454/belum-ditindakdishub-baru-lakukan-pendataan. diakses pada tanggal 8 November 2018. 